\title{
Parodies of Whiteness: Die Antwoord and the Politics of Race, Gender and Class in South Africa
}

\begin{abstract}
The dramatic reconfiguration of the social, political and ideological order in South Africa since 1990/1994 has demanded a concomitant reconceptualization of (white) Afrikaner notions of self and belonging in the (new) nation. In this paper, we draw on recent developments in the study of vari-directional voicing (polyphony), performance and mediatization to examine how the South African rap-rave group Die Antwoord makes use of parody and metaparody in their music to critique emerging 'new Afrikaner' identities and the racial, class and gender configurations on which they are based. We also discuss the structural limits of these critiques and the political potential of (meta)parodic performance more generally.
\end{abstract}

KEYWORDS: (meta)parody, polyphony, performance, race, class, gender, South Africa

In August 2016, ¥o-landi Vi\$\$er, a member of the well-known South African rap-rave group Die Antwoord, took to Instagram to accuse filmmaker Dave Ayer of "jockin our style" in his newlyreleased action film Suicide Squad. Vi\$\$er's post was immediately picked up by a variety of international media outlets, who described it as yet another blow to Ayer's film, which by that point had been almost universally panned by critics. In South Africa, however, Vi\$\$er's statement elicited a combination of bemusement and anger, with hundreds of Twitter users commenting on the irony of her claim. Since its inception in 2010, Die Antwoord has been heavily criticized in South Africa for what many view as its appropriation of so-called Cape Coloured gangster culture, including what some argue is the downright theft of ideas and lyrics from local hip-hop artists (e.g., Haupt 2012). ${ }^{1}$ One Twitter user (@CapeTown_Bru) summarized a component of the local reaction to Vi\$\$er's post succinctly by tweeting a photo of gang members in the Cape Flats, an area of largely poor mixed-race townships near Cape Town, with the caption 'these guys are waiting on their royalties.' This incident encapsulates the extent to which Die Antwoord sits at the heart of ongoing debates about identity, race and power in contemporary South Africa. For some, including the band's many fans, Die Antwoord represents an irreverent and subversive alternative to the rigid lines of racial demarcation that continue to animate South African society, a 'post-racial' attempt to 
move away from the structures of the apartheid past (Marx \& Milton 2011; du Preez 2011). To the band's detractors, however, Die Antwoord is engaged in nothing more than cultural appropriation (i.e., exploiting a culture and lifestyle that is not one's own for commercial gain) and/or modern-day blackface (in which a marginalized population is parodically demeaned and debased) (Haupt 2013; see also Lott 1993; Bucholtz 2011; Bucholtz \& Lopez 2011).

Die Antwoord (Afrikaans for 'the answer’) is comprised of three members (¥o-landi Vi\$\$er, Ninja, and DJ Hi-Tek) who present themselves as white working-class Afrikaners from the Cape Flats. In reality, none of the band members are from the Cape Flats region. ¥o-landi, whose real name is Anri du Toit, grew up in the largely rural Eastern Cape province, while Ninja is Watkin ('Watty') Tudor Jones, an English South African who grew up in the middle-class suburbs of Johannesburg (DJ Hi-Tek is not portrayed by the same person all the time, and is generally much less in the media spotlight than either Vi\$\$er or Ninja). Despite this, the group skyrocketed to prominence in 2010 with the release of their first music videos 'Enter the Ninja' and 'Zef Side'. Both were offered online for free on the local Afrikaans site watkykjy.co.za and on YouTube. According to Badprop (2010, cited in Haupt 2012), the songs were a viral success, launching the band to global fame at breakneck speed. Within eight weeks of having posted the videos, Die Antwoord acquired 30,000 followers on Facebook, their videos were downloaded nearly two million times, and they were signed by a major record label. For many, the group's appeal lay in their mixing of elements of electronic techno dance music with local South African rap/hip-hop, resulting in what the band itself describes as their 'rap rave' style. From a South African perspective, Die Antwoord's music borrows stereotypical elements of both white (Afrikaner) working-class and Cape Coloured culture to create an aesthetic that seemingly focuses on the ‘commonalities between white and coloured identities' (Haupt 2012:115) in South Africa. ${ }^{2}$

This 'hybrid' aesthetic (Marx \& Milton 2011) is often labelled zef, a local category that traditionally meant 'poor white' or 'white trash' but that has since been reclaimed as a positive in- 
group identity marker (similar to 'redneck' in the US or 'chav' in Britain; e.g., Eastman \& Schrock 2008). The term itself originates from the Ford Zephyr, a car that was popular within white working-class communities during the apartheid period. While clearly racialized as white originally, Die Antwoord and others have argued, implicitly or explicitly, that zef now denotes a new class-based positioning that cuts across cultural and racial lines (cf. Labrador 2004 on ideologies on multiracial 'localness' in Hawai'i). Describing his embodiment of the zef aesthetic in 2010, Die Antwoord's Ninja claimed

I represent South African culture. In this place, you get a lot of different things ...

Blacks. Whites. Coloured. English. Afrikaans. Xhosa. Zulu. Watookal ['whatever']. I'm like all these different people, fucked into one person. (cited in du Preez 2011:108)

While Ninja's claim regarding Die Antwoord's use of Xhosa and Zulu language and culture is somewhat disingenuous, it is certainly true that much of the band's artistic output borrows (or appropriates) elements of Cape Coloured language and culture. Because of this, certain scholars and cultural commentators have argued that Die Antwoord could represent a breakthrough in postapartheid race relations, a possible way forward toward a 'post-racial' South Africa (Ballantine 2004; du Preez 2011; Marx \& Milton 2011; C. Scott 2012). According to this account, Die Antwoord promotes not only a 'mixing' of cultures and styles across racial boundaries but also a view of whiteness itself as a situated racial category, one with its own conventions, histories and internally stratified structure (Kreuger 2012; Williams 2016, cf. also Heavner 2007). Other scholars, however, contest this view, questioning the extent to which Die Antwoord actually transcends racial divisions or simply reinscribes them in updated terms (e.g., Haupt 2012). 
Despite their dissimilarity, both of these interpretations rely on a similar understanding of the semiotic design of Die Antwoord's performances (Agha 2011a), and hence of the political message embedded therein. For those who view Die Antwoord as embodying a potentially radical new 'post-racial' position, as well as those who view Die Antwoord as engaging in straightforward (non-parodic) cultural appropriation, the underlying assumption is that the group's style (and particularly its use of elements of Cape Coloured gangster culture) is ascriptive, i.e., that it is a form of uni-directional voicing (Bakhtin 1984) through which the group seeks to lay claim to (or to appropriate) various characteristics, positions and experiences indexed by the style. ${ }^{3}$ In contrast, those who argue that Die Antwoord engages in a form of blackface minstrelsy claim that the group's voicing of Cape Coloured gangster culture serves a parodic function, through which coloured populations on the Cape Flats are evoked in order to be demeaned.

In this article, we argue for the existence of a third interpretation. Drawing on theories of polyphony, performance and metaparody (e.g., Bakhtin 1984; Bauman 1992, 2005, 2011; Coupland 2007; Jaffe, Koven, Perrino \& Vigouroux 2015), we suggest that through the various mediatized objects they create, Die Antwoord works to interrogate and challenge certain consensus views about race, class and gender in present-day South Africa, particularly as manifest within white Afrikaans communities. While they may achieve this by 'appropriating' and mixing aspects of both Cape Coloured and poor-white Afrikaner culture, according to our account, Die Antwoord is neither celebrating a simple 'hybrid' positioning or engaging in straightforward parody of either of these cultures. At the same time, we are aware that it is impossible to speak about the meaning of texts without taking into account how they are understood and recontextualized by listeners (what Agha 2011 b calls a text's uptake formulations; see note 2). Our goal in the current article is, therefore, to provide an analysis both of the ways in which Die Antwoord embeds political critique in its music and other aesthetic products and of the limits of that critique for enabling social change (cf. Chun 
2004, 2009). In doing so, we also hope to contribute to current discussions on the political potential of polyphonic and (meta)-parodic performance more generally.

We begin in the next section with an overview of the ideological context within which Die Antwoord operates. We follow Steyn $(2001,2004,2005)$ in describing how whiteness became a 'dissonant' category in post-apartheid South Africa, one that required reformulating and rehabilitating within a shifting racial order. We go on to suggest that it is these dominant discourses of 'rehabilitated whiteness', and how they intersect with other social categories such as gender and class, that are the target of Die Antwoord's political critique (a critique that, as we will argue, crucially includes Die Antwoord itself). We then turn to an outline of our framework for the study of staged performance (Bell \& Gibson 2011). We focus here on the tactics available for dis/aligning with the voices present in polyphonic performance and the ways in which these dis/alignments relate to the construction of both parodic and metaparodic stances (e.g., Morson 1989; Dentith 2000; Chun 2004, 2007; Coupland 2007; Jaffe 2015). We go on to apply this framework to a detailed analysis of the music video for Die Antwoord's 2012 song 'Baby's on Fire', where we identify a variety of relevant personae that are evoked and positioned throughout the performance. Finally, we examine the potential political ramifications of these positionings, drawing on Bakhtin's (1965) discussion of the carnivalesque.

Before getting underway, we believe that it is crucial for us to position ourselves as analysts of the text in question. Neither of us is a member of either of the relevant social groups (white working-class Afrikaans or Cape Coloured). The first author is a white middle-class Englishspeaking South African (though who has Afrikaans family connections and currently lives and works in an Afrikaans-speaking context), while the second author is a white non-South African who currently lives and works in London. Our interpretations of Die Antwoord's work are naturally influenced by our own backgrounds and social positionings, which are different from members of the social groups invoked in Die Antwoord's music. While it is important for us to bear this in 
mind, we would argue that our perspective is nevertheless an important one since, to a large extent, we represent Die Antwoord's target audience (i.e., white middle-class South Africans and white people abroad). We therefore approach our analysis aware of our positioning outside of the communities in question, though we have also endeavoured to include views (both scholarly and popular) from within the relevant communities wherever possible.

\section{WHITENESS IN POST-APARTHEID SOUTH AFRICA}

With the fall of the apartheid regime in 1990-1994, South Africa became the last country on the continent to end white minority rule. For white Afrikaner South Africans, the country's new democratic dispensation represented an ideological sea change. More than just a political system, apartheid represented the apotheosis of a movement for white Afrikaner cultural empowerment, the culmination of a long-standing project to position white Afrikaner identity at the moral centre of conceptualizations of the nation (e.g., Dubow 1992; Giliomee 2003). This project operated on two fronts. Most prominently, apartheid institutionalized a form of strict racial segregation and subordination based on an uncompromising belief in white cultural, intellectual and physical supremacy (Fredrickson 1981; Steyn 2001). This meant the separation of 'white' individuals from both 'black' and 'coloured' individuals. Within white South African society, dominant discourses distinguished between Afrikaans and English-speaking communities, emphasizing and elaborating a belief in a salient ethnic difference between the two groups (de Villiers 1987; Giliomee 2003). In reality, however, and especially at the lower end of the socioeconomic spectrum, there was much mixing and Afrikaans-English integration among the two white sub-populations, resulting, on a linguistic level, in a fair degree of bilingualism and related phenomena such as code-mixing.

With the rise to power of the National Party in 1948 and the gradual establishment of apartheid, white Afrikaners were eager to demonstrate not only that they could govern a nation, but that they were the best placed to do so (Goldberg 1993; Schutte 1995; Steyn 2001). They based this 
on a belief in their own moral rectitude and purity, qualities that they argued were lacking in both the non-white and the English populations. In other words, a belief in the white Afrikaner community as sole guardian of Christian morality - of temperance, modesty, honesty, and integrity - became the justification for white Afrikaner hegemony and sustained an ideological order in which white Afrikaner dominance was naturalized (Norval 1996; Steyn 2004).

An additional important component of white Afrikaner nationalism was an emphasis on patriarchy. White Afrikaans speakers have, generally, adopted a conservative approach to gender roles, and McClintock (1993:68) has, for one, proposed a clear connection between Afrikaner nationalism and high degrees of patriarchy:

... the invention of Afrikaner nationalism had a clear gender component. In 1918, a small, clandestine clique of Afrikaans men launched a secret society, with the express mission of capturing the loyalties of dispirited Afrikaners and fostering white male business power... The gender bias of the society, as of Afrikanerdom as a whole, is neatly summed up in its name: the Broederbond (the brotherhood). Henceforth, Afrikaner nationalism would be synonymous with white male interests, white male aspirations and white male politics. Indeed, in a recent effort to shore up its waning power, the Broederbond is currently debating whether to admit so-called 'coloured' Afrikaans speaking men into the brotherhood. All women will, however, continue to be barred.

While the transition to a democratic society in 1994 challenged traditional gender roles in South Africa across the board, a recent study by Pretorius (2013) shows clearly that Afrikaans-speaking South Africa remains predominantly hetero-normative and that, in particular, the (white) Afrikaner female stereotype remains a relatively conservative one. 
The end of white dominance in the early 1990s thus involved much more than just a changeover in political power. It transformed whiteness from being the embodiment of (patriarchal) power and privilege into an icon of racial injustice and subjugation, a 'dissonant' positionality (Steyn 2005) in the new South Africa. As such it also served to profoundly destabilize the entire coherence system (Linde 1993) undergirding white Afrikaner subjectivity. This transformation engendered what Steyn (2004:150) describes as

a crisis of Afrikaner identity ... a dislocation ... when the previously unseen or denied is made visible, when the representations and constructions that shaped identities are recognized, and the boundaries of the approved have moved to such an extent that new horizons for the social imaginary have to be forged.

Afrikaners (like other white South Africans) suddenly found themselves obliged to confront questions about their place in South African society, their collective responsibility for past atrocities carried out in their name, and their contribution to the building of a new nation in which ideologies of racial and gender superiority are no longer permitted. In numerous studies spanning nearly two decades of research, Steyn $(2001,2004,2005$; Steyn \& Foster 2008) has described this process as one of 'rehabilitating' whiteness, an attempt to shift the category from a position of 'disgrace' to one of belonging in a changed racial order.

Recently, Blaser and van der Westhuizen (2012) have argued that two of the strategies initially identified by Steyn predominate among white Afrikaner South Africans (see also Steyn 2014). The first is what they term the defensive ethnicization of Afrikaner identity (Visser 2004; Bentley \& Habib 2008). This involves the recasting of Afrikaner identity as an ethnic category, making it legible within a logic of multiculturalism and a discourse of community-based rights. Described by others as semigration (from 'segregation' and 'emigration'; Ballard 2004) or 
inwaartse migrasie ('inward migration'; Coetzee 2008, cited in Blaser \& van der Westhuizen 2012), the strategy is 'defensive' because it is organized primarily around the belief that Afrikaner culture and language is under threat and must be protected from outside pressures to assimilate. In many respects, defensive ethnicization is thus similar to traditional white Afrikaner nationalism, with the exception that, on the surface at least, community boundaries are policed and protected along 'cultural', as opposed to purely racial, lines (Comaroff \& Comaroff 2009) $)^{4}$. The second strategy commonly found among white Afrikaners is the promotion of a depoliticized, neo-liberal, global Afrikanerdom (van der Westhuizen 2007; Davies 2009; Sonnekus 2017), a strategy that is particularly relevant to claims about Die Antwoord's use of cultural appropriation. Unlike ethnicization, this strategy rejects the political undertones of Afrikaner identity and the need to police community boundaries, while nevertheless maintaining an attachment to salient Afrikaner cultural practice. This is because the neo-liberal strategy views Afrikaner-identified 'goods' (e.g., films, music, language, relationships) as desirable commodities to be acquired. While the end-result of this approach may be the same kind of cultural (and often more or less racial) exclusivity that characterizes the defensive ethnicization strategy, the path taken to arrive there is built on individual motivations to consume particular objects (i.e., a commodification of the self; Comaroff \& Comaroff 2009). As strategies for rehabilitating whiteness, both ethnicization and neo-liberalism succeed in casting aside the most invidious aspects of institutionalized white Afrikaner ethnonationalism. Yet, as Blaser and van der Westhuizen (2012:388) argue, these strategies nevertheless often result in the creation of 'self-contained, ethnically demarcated comfort zones' for white Afrikaners in present-day South Africa.

In what follows, we argue that it is precisely these 'comfort zones' of Afrikaner whiteness that Die Antwoord seeks to challenge, through parody and the use of cross-cultural and crosslinguistic elements from both white working-class and Cape Coloured culture. Moreover, we propose that it is not (or not only) ethnicization and neoliberalism as the strategies of others that are 
Die Antwoord's targets (though they are as well). Rather, we suggest that Die Antwoord seeks through the use of metaparody to critique its own complicity in these strategies and, in doing so, to problematize the possibility of closure or resolution more broadly (Jaffe 2009a). In the remainder of the article we describe how this message is materialized in one example of Die Antwoord's music. Before turning to that, however, we first briefly review the conceptual framework we draw upon for analysing polyphony and stance in staged performance.

\section{PERFORMANCE, VOICING, AND (META)PARODY}

Bauman (2004:9) describes (staged) performance as an act of cultural display, in which the 'act of expression itself is ... objectified, lifted out to a degree from its contextual surroundings, and opened up to interpretive and evaluative scrutiny by an audience.' Objectifying culture in this way serves a number of purposes, notable among them the transmission of local knowledge and customs and the re-articulation of a community's values and norms (e.g., Jaffe 2000, 2015). Yet performance does more than simply transmit already existing cultural practices; it can also challenge those practices and be the impetus for cultural change. According to Coupland (2011:582), it is precisely because, as Bauman describes, staged performance 'lifts' culture out of its habitual context that it 'can be transformative, opening up new cultural scenes and social identities for scrutiny and evaluation' (emphasis added). In other words, the processes of decontextualization and objectification inherent in staged performance bring into sharper relief the ideologies and conventions that undergird cultural practice, making it an ideal site for selfreflection and critique.

In semiotic terms, Coupland (2007) argues that the special status of staged performance results from the fact that it involves a number of different types of communicative focusing. While Coupland enumerates seven types of focusing in total, only three concern us here. The first of these is repertoire focusing, whereby the performative frame makes known cultural characters (Agha 
2007) and discourses salient. According to Coupland, repertoire focusing is what helps to create a shared common ground for the performance, enabling audience members to more clearly perceive any deviation from standard cultural expectations. This ability to notice deviations is also aided by form focusing, which involves the foregrounding of the semiotic tools that are deployed in the course of the performance, both verbal and non-verbal (Bakhtin 1981; Bauman 2005). Form focusing is thus responsible for the fact that, during performances, audiences pay closer attention to the way in which things are said and done than they normally would in more mundane (and unmediatized) encounters. Finally, form focusing and repertoire focusing together contribute to meaning focusing, or the tendency to ascribe an 'intensity, a density and a depth' (Coupland 2007:147) to performances. Put another way, meaning focusing refers to our inclination to interpret performances as having a deeper evaluative purpose, i.e., to interpret them as acts of stance-taking with respect to some salient cultural object (Agha 2005; Du Bois 2007; Jaffe 2009b). Taken together, what emerges from Bauman's and Coupland's descriptions of staged (or high) performance is an understanding of it as a form of communicative display in which cultural norms and practices are highlighted and critiqued, as a result of which the performers' own views and positionings with respect to the culture invoked are materialized.

The positionings that performers adopt can themselves range from endorsement to derision, as modelled by Bakhtin's (1984) classic distinction between uni-directional and vari-directional voicing (see also Goffman 1974; Rampton 1995, 2006; Chun 2004, 2007). In the current discussion, we are concerned with positioning via vari-directional voicing, or what, when done within a humorous frame, has been commonly referred to as parody. According to Morson (1989:67), among others, parodic texts are those that a) evoke another text, b) are antithetical to the evoked text, and c) are intended to have higher semantic authority than the original (see also, e.g., Hutcheon 1985; Dentith 2000). Parody is thus a strategy for mocking or deauthenticating some 
contextually relevant 'other', and, in so doing, for positioning the individual(s) enacting the parody as superior in some way (cf. Hastings \& Manning 2004).

The existence of parody in a given performance, however, is often subject to multiple interpretations. The act of deauthenticating one's own parodic practice is what Morson (1989) labels metaparody, or parody whose polemic target is the animator of the text instead of (or in addition to) the text's original author. In other words, in metaparody speakers are not mocking an individual who 'speaks this way', but rather mocking an individual who 'mocks an individual who speaks this way.' Research in sociolinguistics and linguistic anthropology over the past ten years has identified numerous instances of metaparodic language use (e.g., Chun 2004, 2007; Clarke \& Hiscock 2009; Bucholtz 2011; Bucholtz \& Lopez 2011; Gibson 2011; Pietikäinen 2013, 2016), particularly in staged and/or mediatized performances. Chun (2004), for example, provides a detailed analysis of Asian-American comedian Margaret Cho's voicing of a stereotypical 'Asian mother' persona in her stand-up comedy routine. Chun argues effectively that in voicing this character, Cho is not (or not only) mocking the voice's purported 'owner'. She is also mocking, and hence critiquing, the ideological regimes of race in America that enable such mockery to exist (and to be funny) in the first place. Similarly, though in a less ideologically fraught context, Gibson (2011) describes how the New Zealand musical-comedy duo Flight of the Conchords use both parody and metaparody in their 2007 television series of the same name. In one episode, Gibson describes how Brett, one member of the duo, seems to mock his own habit of wearing sweaters with large images of cute animals on them. Yet, as Gibson (2011:619) notes, it is difficult to tell who precisely is the polemic target of this parody: 'Is it the one who wears pictures of cute animals that is being mocked, or is it, by contrast, the pretentiousness of thinking it is uncool to wear pictures of cute animals that is being criticized?'

Teasing apart whether a performance is parodic or metaparodic, and the political ramifications of this interpretation, is at the heart of our analysis below. Building on the work of 
Goffman (1961), we approach this problem by first identifying specific semiotic cues that signal the creation of role dis/alignment between the performer and the evoked text and that thus serve to key (Hymes 1974) the existence of a parodic frame. In particular, our analysis focuses on:

- Exaggeration, of phonetic detail or lexical items (Dentith 2000; Chun 2004; Gibson 2011);

- Juxtaposition, of characters and discourses in incongruent contexts (what we call below 'contiguous dissonance');

- Explicit interdiscursivity, making salient the chain of recontextualizations involved in the creation of the performance (Barrett 1999; Coupland 2001).

What these cues share is an ability to create significant distance between the animator of a given role and the figure portrayed. While we acknowledge that these cues on their own are not necessarily sufficient for the definitive identification of a text as parody, we nevertheless believe that together they allow us to identify the parodic intention of the performers. We return to questions of intention versus uptake in our discussion below.

With respect to the trickier problem of distinguishing metaparody from parody, we rely on Bakhtin's $(1965,1984)$ notion of the carnivalesque. According to Bakhtin (1965:12), carnival is a specific type of parodic performance, one characterised by what he describes as ambivalent laughter, which he contrasts with the negative laughter of pure satire:

The satirist whose laughter is negative places himself above the object of his mockery, he is opposed to it ... Ambivalent laughter, on the other hand, expresses the point of view of the whole world; he who is laughing also belongs to it. 
Carnival is thus metaparody, the use of vari-directional voicing to evoke a polemic target that includes oneself. For Bakhtin, it is the disorienting ambivalence of carnival - absent in pure satire (or parody) - that lends it its regenerative potential, its ability to 'inflect existing attitudes and [cultural] symbols in different directions' (Dentith 1995:75). This ambivalence, or, in Bakhtin's terminology, loophole, serves to 'lend an aspect of ridicule' (Bakhtin 1965:454) to that which is accessible at present. In other words, carnival does not function via simple opposition to the existing system, and even less so by proposing some alternative. Rather, its critical force resides in its insistence on semiotic indeterminacy as a way of highlighting the ridiculousness (and arbitrariness) of the current dominant order (Pietikäinen 2016). Features that are unique to carnivalesque (and thus to metaparody) include a heightened level of self-reflexivity, as well as the presence of grotesque realism, or a focus on depicting (both visually and verbally) the materiality of bodily existence as opposed to its more 'noble' counterpart (e.g., 'love' depicted as 'sex', 'power' depicted as 'blood', etc.). These features are, admittedly, vague and slippery, with the border between parody and metaparody often residing in the eye of the beholder. Nevertheless, we argue in our analysis that Die Antwoord's performance goes beyond simple parody (and/or cultural appropriation) by including elements of heightened self-reflexivity and grotesque realism. We suggest that Die Antwoord does so as a way of enacting a metaparodic positioning that is central to the zef aesthetic they seek to promote.

\section{'BABY'S ON FIRE'}

We illustrate our arguments about the ambivalent meanings of Die Antwoord's work via a close semiotic analysis of the music video for 'Baby's on Fire', a song from the group's second studio album Ten\$ion from 2012. The song tells the story of a brother and sister, ostensibly 'Ninja' and ‘¥o-landi’, and the ways in which 'Ninja’ attempts to prevent '¥o-landi’ from having sexual encounters with local boys. Structurally, the song is divided into a (spoken) prologue followed by 
three verse + chorus sequences and a brief final coda. In the interest of space, we focus here only on the prologue and the first verse + chorus sequence (though the subsequent sequences are similar in structure and content).

\section{Prologue}

The video for 'Baby's on Fire' begins with a fairly lengthy spoken prologue (over two minutes). Given its length and its prominent positioning, it is clear that the prologue serves a crucial role in providing an interpretive framing for the song to come (Coupland 2011). It begins with an 'opening credits' of sorts (see Figure 1), in which two young, white men are pictured riding bicycles that are too small for them in front of a block of flats. Both men are shirtless and one is wearing a balaclava in what is obviously warm South African weather. The same individual has pulled-up socks, while the other is wearing no socks at all. The title of the video, 'Baby's on Fire' is displayed as they go past. For a South African audience, the context depicted is recognizable as indexing both '(urban) poor white' and 'Afrikaans'. This is clear from the exterior of the buildings behind the cyclists, which South Africans would have little problem identifying as emblematic of the white workingclass suburbs of Johannesburg or Cape Town. The pulled-up socks of one of the cyclists is, moreover, an explicit cue to stereotypical Afrikaner dress-sense. The fact that a dog is barking in the background simply adds to the highly stereotypical scene.

\section{[INSERT FIGURE 1 HERE]}

Figure 1: Opening sequence from 'Baby's on Fire' prologue

The prologue then cuts to the interior of one of the houses, where a daytime meal is being enjoyed by a father, mother and their two adult children ('Ninja' and 'Yolandi'). As before, there are strong visual cues of white working-class Afrikaner identity, including the decor, the family 
members' clothing and the food being served. The presence of a bottle of Mrs. Ball's Chutney on the table is a general South African local feature. The mixing of Afrikaans and English is also highly relevant in this regard. The scene is transcribed in its entirety in (1).

(1) Prologue

$1 \quad(($ mother hands plate of food to Ninja))

2 Ninja Mmm, this looks lekker, Ma.

Mmm, this looks delicious Mom.

3 Mom Oh, dis 'n plesier.

It's a pleasure.

4 Dad Dankie.

Thank you.

5

((mother distributes food to everyone around the table $)$ )

6 Ninja Ma, is daar nie iets om te drink nie?

Mom, is there anything to drink?

7 Mom Yolandi, kry vir jou boetie iets om te drink.

Yolandi, get your brother something to drink.

$8 \quad$ Yolandi ((exasperated sigh)

9 Dad Yolandi!

10 Yolandi ((goes to the refrigerator)) Wat soek jy? Coke?

What do you want? Coke?

$11 \quad$ Ninja Redbull 
((Yolandi bends over and reaches into refrigerator. Cut to father inhaling on his cigarette and leering at Yolandi))

((Yolandi brings Ninja the Redbull. He drinks the entire can))

((The family joins hands around the table to say grace))

15 Yolandi Dankie Here vir die lekker kos wat Ma vir ons gemaak het.

Thank you Lord for the delicious food that Mom prepared for us.

16

En dankie dat al ons konserte so mooi uitverkoop het in die oorsee.

And thank you that all of our concerts sold out so well overseas.

En dankie, Here, dat ek sulke nice klere daar kon gekoop het.

And thank you Lord for the nice clothes that I bought over there.

En dankie Here vir Satan.

And thank you Lord for Satan.

((cut to picture of Ninja with dog named Satan))

Oh, en dankie Here dat ek op die voorblad van die nuwe FHM gaan wees.

Oh, and thank you Lord that I'm going to be on the cover of the next FHM magazine.

En seën asseblief die kos wat ons vandag gaan eet. Amen.

And please bless this food that we are about to eat today. Amen.

22 Yolandi Mom can JP come show me his new motorbike today?

23 Ninja Wat? Wie?

What? Who?

24 Yolandi JP. 
25 Ninja No. Not the fuck is that poes coming into this house!

No. Not the fuck is that cunt coming into this house!

26

I don't want that scumbag motherfucker hanging around my little sister! You hear me?

27

$$
\begin{array}{r}
\text { Yolandi Aaw, Ma! } \\
\text { Aaw, Mom! }
\end{array}
$$

28 Ninja No, no, no, no. I don't want any of these scaly motherfuckers from this hood getting fresh with my little sister!

They just got one thing on their minds! You hear me? One thing!

30 Yolandi Whatever. Poes.

Whatever. Cunt.

The interaction in (1) begins with the mother distributing food to the rest of the family (lines 1-5; see Figure 2), an enactment of a traditional gendered division of labour that, while certainly widespread, tends to be heightened in Afrikaner communities (the mother is also wearing a sweatshirt that says 'World's Best Mom'). This adherence to traditional gender norms is further reinforced by the mother's (and father's) insistence that Yolandi fetch something for her brother to drink (lines 7-9), in effect positioning Ninja as the rightful inheritor of patriarchal Afrikaner masculinity. We see this clearly in Ninja's attempt at the end of the prologue (lines 25-29) to control which men Yolandi sees and 'protect' his younger sister's virtue (i.e., a canonical example of benevolent sexism). Finally, Ninja's embodiment of this patriarchal role is signalled linguistically through his use of stereotypically Afrikaner linguistic practices, including a tapped /r/ (i.e., [r]) in Redbull (line 11) and, later, the term poes ('cunt') (line 25) and both TH-fronting and KIT-tensing in the phrase 'one thing' (i.e., [wen fin]) (line 29). 


\section{[INSERT FIGURE 2 HERE]}

Figure 2: Mother distributing food to Ninja and the father during the prologue

In addition to this explicit reference to gendered divisions of labour, the treatment of women in traditional Afrikaner society is also more subtly critiqued in the prologue. While the mother is distributing food around the table, for example, the camera cuts to a shot of some of the pictures hanging on the wall of the family home (see Figure 3). What we see there, however briefly, is a framed photograph of a white kitten caught in a tree with the caption 'I think I need a hug' hanging next to a framed 'pin-up' drawing of a naked woman lying on her side with her legs in the air while with her fingers she is spreading her labia, all of this over a caption that reads 'Inviting pussy'. Similarly, later in the prologue, we see another set of pictures on the wall: this time, a topless female centrefold hanging next to a drawing of a smiling young girl in a field of flowers and a framed image of Jesus. These dissonant juxtapositions of highly sexualized images with syrupy sweet 'kitsch' ones can be read as a parodic commentary on the sexual hypocrisy of conservative Afrikaner culture. This charge of hypocrisy is perhaps nowhere more evident in the prologue than in the depiction of Yolandi's father leering at her as she bends over to retrieve a Redbull from the refrigerator (line 12) (see Figure 4).

\section{[INSERT FIGURE 3 HERE]}

Figure 3. Incongruous juxtapositions of sexual and 'cute' images in the prologue

\section{[INSERT FIGURE 4 HERE]}

Figure 4. The sexualization of Yolandi in the prologue 
Gender is thus one of the principal dimensions of white Afrikaner culture that is evoked in the prologue. Another crucial dimension is age, and particularly the generational divide between the parents and the 'children'. Generational differences are most clearly evident in comparing the clothing and hairstyles of Ninja and Yolandi to those of their parents. Somewhat more subtly, Yolandi's prayer (lines 15-21) establishes a contrast between the religious ethno-nationalism of earlier Afrikaner generations and the more neo-liberal, consumerist articulations of Afrikaner identity popular today (see discussion above). The saying of grace before meals is a very common aspect of Afrikaner cultural life, particularly among more traditional households. The fact that the family joins hands in prayer therefore helps to position them as more conservative and invested in maintaining Afrikaner cultural rites. Yet aside from the formulaic giving of thanks for the food to be consumed, Yolandi's prayer itself focuses on the entirely untraditional themes of acquiring material possessions and achieving financial success (lines 16-17), not to mention a celebration of her own status as a sex symbol (line 20). The prayer is thus yet another example of the incongruent juxtaposition of opposing values in the prologue, used in this instance to delineate a clear generational divide within white working-class Afrikaner society.

The final important cultural phenomenon on display in the prologue is the specific type of femininity that Yolandi embodies. We describe above how traditional Afrikaner gender relations are re-enacted in the prologue, with Ninja and, to a lesser extent, the father positioned as hegemonic masculine patriarchs. Yolandi's feminine persona depicts what can be best described as a hyperfeminine 'nouveau riche' style, associated in the popular imagination with 'aspiring' women from the lower middle-class in cities such as Pretoria. The presence of this persona is most evident in Yolandi's speech, which is characterized by the prominence of certain highly salient Afrikaans sociophonetic features. These include rounded [o:]-like pronunciations of MA vowels in words such as ma and gemaak (line 15), daar (line 17), and Satan (line 18) (cf. Wissing 2009); a lowered EK-vowel in lekker (line 15) and ek (lines 17 and 20); and general fronting of alveolar segments, 
particularly /s/ (especially, for example, in wees in line 20). ${ }^{5,6}$ This speech style, combined with her dress and her focus on money and fame, serve to make Yolandi's character in the prologue an iconic example of an enregistered 'nouveau riche', neoliberal femininity that has emerged within (particularly white) Afrikaner communities over the past 10-15 years, and one that is instantly recognizable to (Afrikaans-speaking) South African listeners.

Taken as a whole, the prologue thus evokes and, we would argue, parodies a number of different contemporary white Afrikaner cultural formations. This first is 'traditional' Afrikaner culture, represented most straightforwardly by the parents, but also by the cultural practices (e.g., family meal, decor, prayer) that are depicted. That this representation is parodic (i.e., varidirectional) is cued by the exaggerated nature of the rituals performed and the incongruous juxtaposition of dissonant symbols encoding starkly different value systems (e.g., conservative Christianity paired with pornography). Together, exaggeration and contiguous dissonance work to deauthenticate (Coupland 2007) traditional Afrikaner culture, pointing out its internal inconsistencies and hypocrisies in an attempt to dislodge its ideological primacy. The other principal cultural formation parodied in the prologue is the consumerist 'nouveau riche' femininity depicted by Yolandi. In this case, while there is some evidence for the explicit juxtaposition of opposing values (as in the combination of sex, materialism and religion in Yolandi's prayer), our primary warrant for reading the performance as parodic is Yolandi's use of hyperbolic linguistic styling. As numerous scholars have argued in the past (e.g., Chun 2004, Gibson 2011), hyperbolic uses of language help to create role distance between the animator and the (staged) figure being animated. In the prologue, Yolandi does not voice an 'authentic'-sounding nouveau riche woman, but rather a caricature of this persona. We therefore argue that this performance too is parodic.

The final, and perhaps most pertinent, point about the prologue (and, in fact, the entire video) worth mentioning is the highly self-reflexive nature of the narrative, and the way in which it intermingles fact and fiction. Most obviously, 'Yolandi' and 'Ninja' in the video refer to ¥o-landi 
and Ninja in reality (i.e., Die Antwoord), though they are not in fact siblings nor are the 'mother' and 'father' their parents. ${ }^{7}$ Other elements of the story, however, do derive from actual events, including Die Antwoord’s sold out tours abroad and ¥o-landi’s appearing on the cover of FHM magazine in 2012. We argue in detail below that it is precisely because of the presence of such a multi-level participant framework in the video - and the ever-present potential for leakage across representational frames that it entails - that an alternative metaparodic reading of Die Antwoord's performance is possible. This multi-level and self-reflexive framework is key to a complete understanding of the prologue and to the way that it 'sets the scene' for the musical performance to come.

\section{Verse}

As we note above, the main body of the video is comprised of three verse + chorus sequences (with a final brief coda following the last chorus). There is a rigidly formulaic structure to these sequences, whereby each verse recounts the story of Yolandi attempting to have sexual relations with a (different) suitor, and each chorus depicting Ninja's increasingly violent strategies for preventing her from doing so. In its entirety, the video therefore tells the story of Yolandi's struggle for sexual liberation against the backdrop of Ninja's persistent refusal to allow her that freedom (more on this below). Because of space limitations (and the similarity across the three sequences), we only discuss the first verse + chorus combination in detail, referencing features of other verses only where necessary (see Appendix for the full lyrics of the song).

\section{[INSERT FIGURE 5 HERE]}

Figure 5. First verse: Yolandi and JP in her bedroom 
The first verse begins with an exterior shot of a young man (no doubt JP, mentioned in the prologue) arriving on his motorbike. We then cut immediately to the inside of Yolandi's bedroom, where a bare-chested JP is reclining on the bed smoking marijuana from a handgun-shaped bong. Yolandi sits nearby smoking a spliff while wearing a baby blue midriff T-shirt with the word 'zef' printed in capital letters across the chest, short pink shorts, and fluffy Pikachu slippers (see Figure 5). The music begins immediately, and throughout the verse we cut between the interior of Yolandi's bedroom and an outdoor scene depicting Yolandi singing and dancing in a parking lot while JP rides his motorbike in circles around her (Figure 6). The lyrics for the first verse are transcribed in (2) (Afrikaans terms are in italics).

(2) Verse I

1 Showtime, motherfucker it's on.

2 Apocalypse now, I'm dropping this bomb.

3 You can't fuck with this song,

4 I'll stick to this spliff, I'm not klapping ['hitting'] this bong.

$5 \quad$ I'm a wild child, I don't wanna go to bed.

6 Oh, shit man sorry but I'm stoned again.

7 Ooh, now everything's getting so psychedelic.

8 When I'm doos dronk [ 'stupid drunk'] then I forget all my fokken ['fucking'] lyrics.

9 Like um, uh, who gives a fuck? Don't worry 'bout it, just blow a kiss to me.

10 I like danger, romance, and mystery.

11 I'm a lucky ducky, get mad shit for free.

12 I rock more bling than $\mathrm{Mr}$. $\mathrm{T}$.

13 I make it look easy cuz it is to me.

14 My daddy says it's lekker fokken spiff ['very fucking cool'] to see, a South African 
cherrie ['sexy woman'] making history.

Beginning with the visual elements, the scene in Yolandi's bedroom is an embodiment of contiguous dissonance, or the juxtaposition of incongruent components described above. The shirtless JP klapping his bong is pictured leaning against a furry pink heart-shaped pillow. The bed itself is covered by a pink and blue bedspread, and there are baby pink curtains hanging in the window and stuffed animals positioned on the night table. On the walls are pictures of kittens and smiley faces, hanging next to red devils, 'Evil Boy' (a character affiliated with South African coloured gangs who is pictured with an oversized erect penis), marijuana leaves and Die Antwoord stickers. Yolandi herself is dressed in pink and blue, wearing Pikachu slippers, and yet smoking a spliff. The interior of Yolandi's bedroom thus presents an explicit juxtaposition of symbols of 'girlishness' (and presumed innocence) with drugs, gang references, and overt sexuality. In this respect, the bedroom is reminiscent of certain kawaii formulations, or the particular brand of commodified Japanese ‘cuteness' (e.g., Kinsella 1995, 2002; Allison 2003, 2006; Akita 2005). Studies of kawaii in Japan and elsewhere have argued that the practice allows women to subvert traditional expectations of adulthood, particularly those involving adherence to strict gender norms. It therefore seems possible to argue that kawaii-like practices are deployed in the video to signal Yolandi's refusal to accommodate Afrikaner (gender) norms and her desire to seek an alternative lifestyle instead.

We get a clue as to what this 'alternative lifestyle' is that Yolandi seeks in the portions of the verse that take place outside (see Figure 6). There, as we note above, Yolandi is shown dancing while JP rides his motorbike in circles around her. In later verses, this is repeated with another potential suitor driving his car around her in circles (and even at one point getting out of the car to stand on the hood while the car continues spinning on its own). The spinning of the motorbike (and, later, the car) are instances of a practice called drifting, something that is popular throughout 
working-class South Africa, but is particularly associated with townships and the Cape Flats (Quentin Williams, pers comm). The depiction of drifting in the chorus is thus an explicit reference (along with Evil Boy and various other motifs) to the Cape Coloured and working-class culture that Yolandi aspires to. In the other verses, additional intertextual references of this kind include the presence of recognizable Cape Coloured graffiti, the wearing of South African orange prison garb by one of Yolandi's paramours, and Yolandi's use of hand signs that are associated with gangs in the Cape Flats.

\section{[INSERT FIGURE 6 HERE]}

\section{Figure 6: Yolandi and drifting}

Finally, another clue to Yolandi's desired lifestyle comes from the linguistic content and form of the lyrics in (2). Generally, we see a complete shift away from the hyper-feminine 'nouveau riche' linguistic style that Yolandi used in the prologue. ${ }^{8}$ There are a number of lexical items that strongly signal the local South African context, including lekker (in this case, 'very'), spiff ('cool'), and cherrie ('sexy woman'). There are also terms that are explicitly associated with working-class and/or coloured varieties of Afrikaans (doos dronk 'stupid drunk', klapping 'hitting', fokken 'fucking'). In addition, there are also a number of phonetic features that are highly stereotypical of Afrikaans-influenced English in South Africa and which generally index a working-class identity, whether white or coloured. These include the de-aspiration of voiceless stops in words like showtime (line 1); the use of obstruent (as opposed to approximant) /r/ in motherfucker (line 1), dropping (line 2), sorry (line 6) and elsewhere; a very high DRESS vowel in the word again ([əgen]; line 6); the devoicing of word-final consonants in is ([is]; line 13); and a very high-front KIT vowel in the same word (see also, e.g., Williams 2016 on what he terms Cape Flats English). Lastly, there are a number of terms that can be said to derive broadly from Hip Hop Nation 
Language (Alim 2004), including rock and bling (line 12), not to mention the generalized use of braggadocio (e.g., Smitherman 2006) throughout. What's more, the content of Yolandi's lyrics combines braggadocio with an overt indifference (or even disdain) for musical production (Iforget all my fokken lyrics, who gives a fuck). This combination resonates with other 'anti-establishment' music groups that have been described in the literature, both in South Africa (e.g., Fokofpolisiekar; Marx \& Milton 2011) and elsewhere (e.g., Sex Pistols; Coupland 2011).

In summary, we can see that the first verse, like the verses that follow, works to construct and position an anti-establishment, racially-hybrid and working-class zef persona that provides Yolandi with an escape from the articulations of traditional white Afrikaner identity in the prologue. This persona is explicitly identified both linguistically and visually as working-class and local (i.e., South African), and attempts are made to transcend boundaries of language (English vs. Afrikaans) and, more implicitly, race (white vs. coloured). While the precise contours of the zef persona are not fully delineated, it is clear that the Yolandi depicted in the song's verses offers a complete contrast with the more traditional 'ethnic' Afrikaner whiteness of her parents, as well as with the patriarchal privilege embodied by both her 'father' and 'brother'. With respect to the globalized, consumerist Afrikaner whiteness of her character in the prologue, things are somewhat more ambiguous. While Yolandi's use of working-class elements, for example, creates a degree of distance between her character in the prologue and her character in the verses, the trope of self-reflexivity and selfcritique remains (e.g., in the use of Die Antwoord stickers on the bedroom's walls).

\section{Chorus}

The chorus following each of the verses is sung by both Ninja and Yolandi. In each chorus, Ninja is somehow alerted to the presence of a man in Yolandi's bedroom (e.g., by smelling marijuana being smoked in her bedroom, by having her brassiere land on his head after having been thrown out of her window, etc.). Once aware of this, Ninja stops what he is doing (which inevitably involves 
entertaining a group of scantily clad women), grabs a weapon of some kind (a baseball bat, a sword, a handgun), and goes into Yolandi's room to confront the man that is there. The lyrics of the chorus are transcribed in (3).

Ninja Baby's on fire. She's got me going fokken ['fucking'] crazy soos ' $n$ mal naaier ['like a crazy fucker'].

Yolandi O jirre God se Jesus [roughly 'Oh Lord, God's Jesus']. (repeats $\mathrm{x} 2$ )

Ninja Baby's on fire. (repeats x3)

The first chorus begins in Ninja's bedroom, with Ninja lying on the bed in a pair of marijuana leaf boxer shorts accompanied by two women dressed only in their underwear (see Figure 7). One of these women is stroking Ninja's bare chest, while the other is fingering through a fistful of money. A third woman, also in her underwear, is shown dancing with a boom box placed strategically in front of her chest at the foot of the bed. The presence of the women, the boom box, the money, and the images of marijuana leaves all conspire to make this opening scene of the chorus a subversive pastiche (Coupland 2011) of globalized hip-hop, referencing pervasive stereotypes of drug consumption and the 'pornification' (Hunter \& Soto 2009; Hunter 2011) of the genre. At the same time, the bedroom also evokes stereotypical (white) Afrikaner masculinity. A stuffed kudu head is hanging on the wall behind the bed, and the bed itself is covered by a leopardskin bedspread. These two elements clearly point to big-game hunting, a central component of traditional Afrikaner masculinity (e.g., Goodrich 2015). The combination of over-the-top and highly stereotypical references to global hip-hop and traditional Afrikaner masculinity make clear that the opening scene of the chorus is a parody of 'updated' white Afrikaner masculinity, a mockery of a 
new generation of men that clumsily appropriates elements of a perceived 'cool' hip-hop lifestyle and incorporates them into more traditional (and racially-defined) Afrikaner cultural practices. Crucially, it is Ninja (i.e., a member of Die Antwoord) who embodies this style of Afrikaner masculinity in the video and is being derided in this regard. This fact provides another clue that what Die Antwoord is parodying includes Die Antwoord itself.

\section{[INSERT FIGURE 7 HERE]}

Figure 7. Chorus: Ninja in his bedroom

Yolandi's appearance in the chorus reinforces the parodic dismissal of the culture and values that Ninja's character represents. While the majority of the chorus focuses on Ninja, first in his bedroom and then as he seeks out Yolandi's sexual partner, the camera periodically cuts to images of Yolandi dancing in a sexually suggestive fashion outside. At these moments, Yolandi utters the line O jirre God se Jesus, a nonsensical blasphemous phrase (it translates roughly as 'Oh Lord God's Jesus). This phrase is explicitly designed to shock traditional Afrikaner sensibilities, and appears to function as an outright rejection of traditional Afrikaner values and practices (of which religious devotion is central). ${ }^{9}$ Yolandi's character in the chorus, like in the verse that precedes it, thus materializes an assertion of zef as a new cultural formation, distinct from traditional articulations of Afrikaner whiteness, while also ambiguously and self-critically linked to recent neoliberal formations. We argue that Yolandi's character thus embodies a metaparodic (i.e., carnivalesque) function. In the chorus in particular, Yolandi's combination of extreme blasphemy with open sexuality is clear an example of grotesque realism, a key element of the carnivalesque.

\section{DISCUSSION}


As we illustrate for the prologue and first verse + chorus sequence, the video for Die Antwoord's 'Baby's on Fire' depicts four distinct culturally salient figures (though two of these figures inhere in the same fictional 'Yolandi'). First is the traditional 'poor white' Afrikaner represented by the parents. With their adherence to traditional gender roles, their outdated taste in clothing and household decor, and their powerlessness to control (or even comprehend) the behaviour of their 'children', the parents evoke an ethnic understanding of Afrikaner whiteness, one based on the maintenance of traditional culture, racial exclusivity and an 'inward migration' (Blaser \& van der Westhuizen 2012) within contemporary South Africa. In contrast, two additional Afrikaner identities are depicted that we argue represent attempts at 'rehabilitating' Afrikaner whiteness (e.g., Steyn 2001): the neoliberal, consumerist 'nouveau riche' Afrikaner of Yolandi in the prologue and the 'global hip hop' Afrikaner of Ninja throughout the video. Finally, there is the zef persona embodied by Yolandi in the verses and the chorus, presented as a new (and, we argue, carnivalesque) alternative to the others.

The textual properties of the video make it clear that of these four representations (i.e., traditional 'poor white', neoliberal/consumerist, global hip-hop, and zef), the first three are clearly the object of parody. This is evident from the ways in which tactics like exaggeration, contiguous dissonance and explicit intertextual reference are used to create significant distance (Goffman 1961) between the animator of a given role and the figure portrayed. We describe above, for example, how the incongruous juxtaposition of religious devotion and sexual licentiousness in the parents' kitchen signals a vari-directional frame in the prologue. Similarly, Yolandi's exaggerated phonetic performance of neoliberal 'nouveau riche' femininity keys us to understand that the persona she is voicing is not to be taken seriously. The same, finally, can be said for the way Ninja's 'hip-hop masculinity' is evoked via an over-the-top visual pastiche of a hip-hop video (complete with half-naked women, drugs, and money) taking place in a room decorated like a 
traditional biltong hunting lodge. In short, the representations of these three figures straightforwardly fits standard definitions of parodic performance.

We would argue, however, that Yolandi's zef persona, while admittedly somewhat harder to pin down, displays features of metaparody. As we note above, some scholars have taken zef to denote a new hybrid working-class cultural positioning, one that attempts to transcend traditional boundaries of race in South Africa through a potentially problematic form of cultural appropriation (e.g., du Preez 2011). More often, however, zef has been viewed as a form of parody, a performative enactment of Cape Coloured culture that is ultimately demeaning and derogatory (e.g., Haupt 2012; C. Scott 2012). We agree that from a formal perspective, zef has many of the characteristic features of parody: we find lexical and phonetic exaggeration in Yolandi's speech when she voices a zef persona; there is consistent and explicit intertextual reference to Cape Flats gangs throughout the video (drifting, Evil Boy, localized hip-hop and graffiti) ${ }^{10}$; and Yolandi's bedroom is a textbook example of incongruent juxtaposition. Nevertheless, we believe that another analysis of zef in 'Baby's on Fire' is possible. While we recognize Yolandi's voicing of zef as varidirectional in nature, we suggest it may fulfil a metaparodic, rather than simply parodic, function.

We base this assertion on a reading of Die Antwoord's construction of the zef aesthetic as a form of carnivalesque performance When examined closely, Die Antwoord's portrayal of zef in 'Baby's on Fire' has all of the hallmark characteristics of carnival. One of these is the prevalence of grotesque realism, or a focus on depicting the materiality of bodily existence and the debasement of more noble concepts: there is plenty of evidence in the video of overt sexuality, violence, swearing and blasphemy. Most important, though, is the heightened self-reflexivity that characterizes 'Baby's on Fire', the 'sideward glance' (Bakhtin 1984:232) that Die Antwoord casts at us throughout the video. From both the content of the lyrics and a variety of different visual symbols (e.g., the word 'zef' printed on Yolandi's T-shirt, Die Antwoord stickers on her bedroom walls, etc.), we are continually reminded that we are watching Die Antwoord portray ‘Die Antwoord’, ¥o- 
landi portray 'Yolandi'. ${ }^{11} \mathrm{We}$ contend that it is this persistent and heightened self-reflexivity that, along with grotesque realism, can ultimately serve to signal a carnival frame, and so warrant an interpretation of the depiction of zef as metaparodic.

Seeing the video (and Die Antwoord's work more generally) as metaparody would mean that its aim is not to demean, parody or unselfconsciously appropriate Cape Coloured culture. Instead, we suggest that the construction of zef could serve as a form of ambivalent laughter, a statement of the arbitrariness (and ridiculousness) of the current South African racial order (and, by extension, of Die Antwoord as savvy cultural commentators able to diagnose the situation; cf. Gal 2009; Jaffe 2016). Under this reading, zef would, ironically, not be offered as an Answer. It would instead serve as a restatement of the problem, an attempt to unsettle existing racial categories yet without offering an alternative (see also Sonnekus 2017). Having said this, we are nevertheless fully cognizant that the potential metaparodic function of $z e f$ still operates via the decontextualization and appropriation of symbols and practices from a different culture and in ways that are often perceived as disrespectful and inappropriate (Haupt 2012, 2013). As Rustum Kozain, South African poet and academic, commented, 'To me, Die Antwoord is basically blackface and blackface is tricky; it exists on a continuum from satire to parody to mimicry to misdirected appropriation, but the points on the continuum are given valency by reception' (cited in Haupt 2012:126). Kozain's comments remind us that any message can have numerous uptake formulations (Agha 2011b), making it impossible to speak of a single definitive 'message' a mediatized object communicates. In addition to this interpretive indeterminacy, there is also the fact that Die Antwoord and its members (i.e., Andri du Toit and Watkin Tudor Jones) have accrued significant amounts of fame and material capital by appropriating the symbolic value of practices that are not originally their own. Regardless of their political intentions in doing so, the distributional reality of South Africa is such that the opportunity afforded Die Antwoord to convert elements of Cape Coloured culture into a marketable product is an opportunity not available to the 
individuals who created those cultural practices to begin with. Ultimately, what this means is that any metaparodic message entailed in Die Antwoord's performance always exists (and must be evaluated) in relation to its potentially problematic repackaging of existing semiotic resources. Put another way, it is not just that metaparody is in the eye of the beholder, but that 'beholding' itself is sensitive to a variety of positional concerns and constraints (Chun 2007 2009; Agha 2011b).

\section{CONCLUSION}

In this article, we have argued that Die Antwoord's 'Baby's on Fire' serves as a parodic critique of various attempts at 'rehabilitating' Afrikaner whiteness in contemporary South Africa. In some cases, this critique functions via parody, i.e., the voicing of salient person-types for the purposes of derision. This, we argue, is what occurs with respect to defensive 'ethnic' formulations of white Afrikaner identity (represented by the parents in the prologue) as well as 'neoliberal/globalized' articulations (as represented by Yolandi's 'nouveau riche' persona in the prologue and Ninja's 'hip hop' persona throughout). In parodying these different kinds of whiteness currently circulating in the South African context, the video succeeds in racializing whiteness and rendering it a marked category that is internally heterogeneous (e.g., Heavner 2007; Steyn \& Foster 2008). We also explore the possibility that, in addition to these parodic critiques, Die Antwoord works to position $z e f$ as a form of metaparody, an ambivalent commentary on the unresolved state of race relations in contemporary South Africa. It is this process that we argue operates via the prism of carnival, through which zef is portrayed neither as something to aspire to (i.e., an ascriptive category) nor as a simple mockery of Cape Coloured and working-class culture (i.e., parody).We nevertheless concede that Die Antwoord's use of Cape Coloured culture to scaffold and support zef is problematic for both symbolic and material reasons.

This point brings us to the larger question of the efficacy of metaparody as a strategy for critical commentary more generally. While we do not have the space to discuss the issue here in 
detail, we note that there are lengthy discussions in the literature on the viability of (meta)parody as a tool in political projects of subversion, including, prominently, Butler's (1993) argument that parodic imitation can destabilize the apparent fixity of entrenched cultural norms and categories (see also, e.g., Hill 1998; Lloyd 1999, 2007; Brickell 2005; as well as recent discussions of infrapolitics, e.g., J. Scott 2012). Yet Butler herself notes that parody is not, by itself, subversive. Rather, it involves a subversive potential that is only realised if a parodic act is interpreted as such by others. For this reason, it is helpful to think of parody as a semiotic phenomenon, which - like all forms of mimetic practice (Lempert 2014) - functions by drawing attention to the difference between a given cultural model (i.e., a persona) and its in-the-moment enactment (Gal 2016). In other words, parodic imitations function precisely because they are not perfect imitations. They are embodied tokens of behaviour that are strategically differentiated from their source-types (Agha 2007), and it is the marking of a difference between token and type that is the locus of potential critique. But, crucially, this difference cannot be said to exist outside of the interpretive process through which it emerges. Put another way, parodic differentials are discursive accomplishments and depend for their meaning not only on the formal properties of the message (i.e., type-token enactments) but also on the way in which that type-token relationship is interpreted by perceivers. Thus, while our goal in the current article has been to argue that "Baby's on Fire" contains a multiplicity of different potential messages that are signalled by the textual structure of the video itself, we also reaffirm the impossibility of categorizing this practice as (meta)parodic without a close ethnographic analysis of how the messages are received (and the systemic and structural factors that influence that reception). Ultimately then, we hope to have demonstrated the complex political potential of mediatized performances like Die Antwoord's, and would encourage further research in South Africa and elsewhere on the factors that constrain whether such potentials are realised. 


\section{NOTES}

1 'Coloured' is a racial category in South Africa, used by the apartheid government to refer to individuals who were not easily classifiable into either of the dominant racial groupings (i.e., 'white' or 'black'). Today, the term 'coloured' is still in widespread use, though its meaning has fragmented to include both a racial classification and a more particular cultural affiliation (Adhikari 2005; Williams \& Stroud 2014).

2 It is important to note that not everyone recognizes (or agrees) with the contention that what Die Antwoord is doing is blending aspects of both white working-class Afrikaner culture and Cape Coloured culture. This became immediately apparent to us in the reactions we received from different readers of earlier versions of this article. In general, white (Afrikaans) readers interpret much of Die Antwoord's behaviour as being grounded almost exclusively in white working-class Afrikaner culture, while, in contrast, readers from the coloured community have been unambiguous in their general condemnation of Die Antwoord's appropriation (and parodying) of what they identify as Cape Coloured cultural elements. We believe that part of this discrepancy in interpretation may be due to the fact that the specific music video we examine here, 'Baby's on Fire', is somewhat less explicit in its Cape Coloured references than many of the band's other songs. Nevertheless, this ambiguity of interpretation is also clearly related to the material reality of contemporary South Africa, and to struggles over authenticity and authorization to engage in certain salient indexical practices. We return to this structural difference in uptake formulations (Agha 2011b) in the general discussion of our analysis.

3 This particular 'uptake' is found in much public discourse. For example, in 2012, a group called Die Vraag ('the question') released a hit song on YouTube called 'Dankie vir die antwoord' ('Thanks for the answer'), in which they 'ask' Die Antwoord what question the band thinks it is the answer for. Marx and Milton (2014) describe how Die Vraag deploy 
parody to mock Die Antwoord's style (and success), and in so doing to make an important critique about social class differences within white South African communities. While we agree that the point about intersections of class and race in the South African context is an important one, we nevertheless maintain that Die Vraag's parodic critique is itself based on a potential misreading of Die Antwoord's original political intention. Thanks to Mark de Vos for reminding us that although much of the discourse of defensive ethnicization is focussed on language and culture (and explicitly not on race), there is merit in perceiving some of the underlying motivations as ultimately racist in nature, despite the surface rhetoric.

5 Our use of the terms 'MA-' and 'EK-vowels' is modelled on Well's (1982) system of lexical sets for describing the vowels of English. Thus, the MA lexical-set consists of words that are generally pronounced the same: in contradistinction to the hyper-feminine variant mentioned in the main text, it is usually [a:] in Standard White Afrikaans or [a:] in Coloured Afrikaans. The EK lexical-set is composed of words such as ek ('I'), lekker ('nice, delicious'), pret ('fun'), etc. Note that Afrikaans does not display a phonemic distinction between a canonically [e] or [ع]-like vowel and a canonically [æ]-like vowel, as in the distinction between English DRESS and TRAP. The EK-vowel in Afrikaans can thus range from a high-front [I]-like position to a low-front [æ] or [a]-like position; generally the lower the vowel, the more prestigious the indexical value.

6 The use of this linguistic stereotype by 'Yolandi' here is arguably somewhat inaccurate, given that, as Authors (2017) show, while fronted /s/ in particular is associated with heightened femininity in the Afrikaans-speaking speech-community, it is not associated with the 'harder' forms of neo-liberal consumerism that are instead more closely linked to stereotypes of South African English women. This is not the place however to discuss possible subtle differences between the performative use of a stereotype and the linguistic 
reality that informs it: the semiotic intent of the use of this stereotype within the context of this text is clear enough.

7 Of course, Ninja and ¥o-landi are themselves fictional characters. We thus have multiple layers of overlapping participant frameworks.

8 Andy Gibson (pers comm) points out that it is perhaps telling that we get such a shift in Yolandi's style from the spoken prologue to the sung verses, and that this shift may be related to various aesthetic/artistic choices related to speech versus singing. We agree that this is an interesting point, but one that we are unable to pursue here.

9 Whenever we have presented this research to white Afrikaans audiences in South Africa, Yolandi's use of this phrase consistently prompts audible gasps, discomfort and/or anger.

10 In other Die Antwoord videos, Ninja's tattoos are another clear example of such intertextual reference (or appropriation). These tattoos do not receive much prominence in the current video.

11 This trope of self-reflexivity is heightened even further when, later in the video, Yolandi is given, as a present from one of her paramours, a doll depicting herself.

\section{REFERENCES}

Adhikari, Mohamed. 2005. Not white enough, not black enough: Racial identity in the South African coloured community. Athens: University of Ohio Press.

Agha, Asif. 2005. Voice, footing, enregisterment. Journal of Linguistic Anthropology 15:38-59.

-2007. Language and social relations. Cambridge: Cambridge University Press.

- 2011a. Commodity registers. Journal of Linguistic Anthropology 21:22-53. 2011b. Meet mediatization. Language \& Communication 31:163-70.

Akita, Kimiko. 2005. Cuteness: The sexual commodification of women in the Japanese media. In 
Theresa Carilli \& Jane Campbell (eds.), Women and the media: Diverse perspectives, 44-57. Oxford: University Press of America.

Alim, H. Samy. 2004. Hip hop nation language. In Edward Finegan \& John Rickford (eds.), Language in the USA: Themes for the twenty-first century, 387-409. Cambridge: Cambridge University Press.

Allison, Anne. 2003. Portable monsters and commodity cuteness: Pokémon as Japan's new global power. Postcolonial Studies 6:381-95.

2006. Millennial monsters: Japanese toys and global imagination. Berkeley: University of California Press.

Badprop, Angola. 2010. Netting an audience. The Media, June 24-28.

Bakhtin, Mikhail. 1965. Rabelais and his world. Bloomington: Indiana University Press. 1981. The dialogic imagination: Four essays. Austin: University of Texas Press. 1984. Problems in Dostoevsky's poetics. Minneapolis: University of Minnesota Press.

Ballantine, Christopher. 2004. Re-thinking 'whiteness'? Identity, change, and 'white' popular music in post-apartheid South Africa. Popular Music 23:105-31.

Ballard, Richard. 2004. Assimilation, emigration, semigration, and integration: 'White' people’s strategies for finding a comfort zone in post-apartheid South Africa. In Natasha Distiller \& Melissa Steyn (eds.), Under construction: 'Race' and identity in South Africa today, 51-66. Johannesburg: Heinemann.

Barrett, Rusty. 1999. Indexing polyphonous identity in the speech of African American Drag Queens. In Mary Bucholtz, A. C. Liang, \& Laurel Sutton (eds.), Reinventing Identities, 31331. Oxford: Oxford University Press.

Bauman, Richard. 1992. Performance. In Richard Bauman (ed.), Folklore, cultural performances, and popular entertainments, 41-49. Oxford: Oxford University Press. 2004. A world of others' words: Cross-cultural perspectives on inter-textuality. Oxford: 
Blackwell.

. 2005. Commentary: Indirect indexicality, identity, performance: Dialogic observations. Journal of Linguistic Anthropology 15:145-50.

2011. Commentary: Foundations in performance. Journal of Sociolinguistics 15: 707-20.

Bell, Allan, \& Andy Gibson. 2011. Staging language: An introduction to the sociolinguistics of performance. Journal of Sociolinguistics 15:555-72.

Bentley, Kristina, \&Adam Habib. 2008. Racial redress, national identity \& citizenship in postapartheid South Africa. In Kristina Bentley \& Adam Habib (eds.), Racial Redress and Citizenship in South Africa, 3-32. Cape Town: HSRC Press.

Blaser, Thomas, \& Christi van der Westhuizen. 2012. The paradox of post-apartheid 'Afrikaner' identity: Deployments of ethnicity and neo-liberalism. African Studies 71:380-90.

Brickell, Chris. 2005. Masculinities, performativity and subversion: A sociological reappraisal. Men and Masculinities 8:24-43.

Bucholtz, Mary. 2011. Race and the re-embodied voice in Hollywood film. Language \& Communication 31:255-65.

Bucholtz, Mary, \& Quiana Lopez. 2011. Performing blackness, forming whiteness: Linguistic minstrelsy in Hollywood film. Journal of Sociolinguistics 15:680-706.

Butler, Judith. 1993. Critically Queer. In Bodies that matter: On the discursive limits of sex, 22342. London: Routledge.

Chun, Elaine. 2004. Ideologies of legitimate mockery: Margaret Cho’s revoicing of Mock Asian. Pragmatics 14:263-89.

- 2007. The meaning of mocking: Stylizations of Asians and preps at a US high school. Unpublished PhD dissertation. Austin: University of Texas at Austin.

. 2009. Speaking like Asian immigrants: Intersections of accommodation and mocking at a U.S. High School. Pragmatics 19:17-38. 
Clarke, Sandra, \& Philip Hiscock. 2009. Hip-hop in a post-insular community: Hybridity, local language, and authenticity in an online Newfoundland rap group. Journal of English Linguistics 37:241-61.

Coetzee, Stef. 2008. Skep so 'n tuiste vir almal [This is how to create a home for everyone]. Rapport, November 4.

Comaroff, John, \& Jean Comaroff. 2009. Ethnicity Inc. Chicago: University of Chicago Press.

Coupland, Nikolas. 2001. Language, situation and the relational self: Theorizing dialect-style in sociolinguistics. In Penelope Eckert \& John Rickford (eds.), Style and sociolinguistic variation, 185-210. New York: Cambridge University Press.

. 2007. Style: Language variation and identity. Cambridge: Cambridge University Press. . 2011. Voice, place and genre in popular song performance. Journal of Sociolinguistics $15: 573-602$.

Davies, Rebecca. 2009. Afrikaners in the new South Africa: identity politics in a globalized economy. London: Taurus Academic Studies.

Dentith, Simon. 2000. Parody. London: Routledge.

Du Bois, John. 2007. The stance triangle. In Robert Englebretson (ed.), Stancetaking in discourse, 139-82. Amsterdam: John Benjamins.

Dubow, Saul. 1992. Afrikaner nationalism, apartheid and the conceptualization of 'race'. The Journal of African History 33:209-37.

Eastman, Jason, \& Douglas Schrock. 2008. Southern rock musicians' constructions of white trash. Race, Gender \& Class 15:205-19.

Fredrickson, George. 1981. White supremacy: A comparative study of American and South African history. Oxford: Oxford University Press.

Gal, Susan. 2009. Perspective and the politics of representation: A commentary. In Angela Reyes \& Adrienne Lo (eds), Beyond Yellow English: Toward a linguistic anthropology of Asian Pacific 
America, 325-8. Oxford: Oxford University Press.

2016. Sociolinguistic differentiation. In Nikolas Coupland (ed.), Sociolinguistics:

Theoretical debates, 113-35. Cambridge: Cambridge University Press.

Gibson, Andy. 2011. Flight of the Conchords: Recontextualizing the voices of popular culture. Journal of Sociolinguistics 15:603-26.

Giliomee, Hermann. 2003. The Afrikaners: Biography of a people. Cape Town: Tafelberg.

Goffman, Erving. 1961. Encounters: Two studies in the sociology of interaction. Indianapolis: Bobbs-Merrill. 1974. Frame analysis. Cambridge, MA: Harper and Row.

Goldberg, David. 1993. Racist culture: Philosophy and the politics of meaning. Oxford: Blackwell. Goodrich, Andre. 2015. Biltong hunting as a performance of belonging in post-apartheid South Africa. Lanham: Lexington Books.

Hastings, Adi, \& Paul Manning. 2004. Introduction: Acts of alterity. Language \& Communication 24:291-311.

Haupt, Adam. 2012. Static: Race and representation in post-apartheid music, media and film. Cape Town: HSRC Press.

- 2013. Citizenship without representation? Blackface, misogyny and parody in Die Antwoord, Lupé Fiasco and Angel Haze. Communicatio 39:466-82.

Heavner, Brent. 2007. Liminality and Normative Whiteness: A critical reading of poor white trash. Ohio Communication Journal 45:65-80.

Hill, Jane. 1998. Language, race and white public space. American Anthropologist 100:680-89.

Hunter, Margaret. 2011. Shake it, Baby, Shake it: Consumption and the new gender relation in hip hop. Sociological Perspectives 54:15-36.

Hunter, Margaret \& Kathleen Soto. 2009. Women of color in hip hop: The pornographic gaze. Race, Gender \& Class 16:170-91. 
Hutcheon, Linda. 1985. A theory of parody: The teachings of twentieth-century art forms.

Champaign: University of Illinois Press.

Hymes, Dell. 1974. Foundations in sociolinguistics: An ethnographic approach. Philadelphia: University of Pennsylvania Press.

Jaffe, Alexandra. 2000. Comic performance and the articulation of hybrid identity. Pragmatics 10:39-59.

. 2009a. Indeterminacy and regularization: A process-based approach to the study of sociolinguistic variation and language ideologies. Sociolinguistic Studies 3:229-51.

. 2009b. Introduction: The sociolinguistics of stance. In Alexandra Jaffe (ed.), Stance:

Sociolinguistic perspectives, 3-28. Oxford: Oxford University Press.

- 2015. Staging language on Corsica: Stance, improvisation, play, and heteroglossia.

Language in Society 44:161-86.

- 2016. Indexicality, stance and fields in sociolinguistics. In Nikolas Coupland (ed.), Sociolinguistics: Theoretical debates, 86-112. Cambridge: Cambridge University Press.

Jaffe, Alexandra, Michèle Koven, Sabine Perrino, \& Cécile Vigouroux. 2015. Introduction:

Heteroglossia, performance, power and participation. Language in Society 44:135-39.

Kinsella, Sharon. 1995. Cuties in Japan. In Brian Moeran and Lise Scov (eds.), Women, media and consumption in Japan, 220-54. Honolulu: University of Hawai'i Press.

- 2002. What's behind the fetishism of Japanese school uniforms? Fashion Theory 6:21537.

Kreuger, Anton. 2012. Zef/poor white kitsch chique: Die Antwoord's comedy of degradation. Safundi: The Journal of South African and American Culture 13:399-408.

Labrador, Roderick. 2004. 'We can laugh at ourselves': Hawai'i ethnic humor, local identity and the myth of multiculturalism. Pragmatics 14:291-316.

Lempert, Michael. 2014. Imitation. Annual Review of Anthropology 43:379-95. 
Linde, Charlotte. 1993. Life stories: The creation of coherence. Oxford: Oxford University Press.

Llyod, Moya. 1999. Performativity, parody, politics. Theory, Culture \& Society 16 (2): 195-213. 2007. Radical democratic activism and the politics of resignification. Constellations $14: 129-46$.

Lott, Eric. 1993. Love and theft: Blackface minstrelsy and the American working class. Oxford: Oxford University Press.

Marx, Hannelie, \& Viola Milton. 2011. Bastardised whiteness: 'Zef' culture, Die Antwoord and the reconfiguration of contemporary Afrikaans identities. Social Identities: Journal for the Study of Race, Nation and Culture 17:723-45.

. 2014. Musical Parody, 'zef', and the Politics of belonging: 'Dankie vir die antwoord maar wat was die vraag?' Muziki: Journal of Music Research in Africa 11:19-37.

McClintock, Anne. 1993. Family feuds: Gender, nationalism and the family. Feminist Review $44: 61-80$.

Morson, Gary. 1989. Parody, history, metaparody. In Gary Morson and Caryl Emerson (eds.), Rethinking Bakhtin: Extensions and challenges, 63-86. Evanston: Northwestern University Press.

Norval, Aletta. 1996. Deconstructing apartheid discourse. London: Verso.

Pietikäinen, Sari. 2013. Multilingual dynamics in Sámiland: Rhizomatic discourses on changing language. International Journal of Bilingualism 19:206-25.

. 2016. Critical debates: Discourses, boundaries and social change. In Nikolas Coupland (ed.), Sociolinguistics: Theoretical debates, 263-81. Cambridge: Cambridge University Press. du Preez, Amanda. 2011. Die Antwoord gooi zef liminality: Of monsters, carnivals and affects. Image \& Text 17:102-18.

Pretorius, Deidre. 2013. The visual representation of masculinities in Huisgenoot Tempo magazine. Communicato 39: 210-32. 
Rampton, Ben. 1995. Crossing: Language and ethnicity among adolescents. London: Longman.

- 2006. Language in late modernity: Interaction in an urban school. Cambridge: Cambridge University Press.

Schutte, Gerhard. 1995. What racists believe. London: Sage.

Scott, Claire. 2012. Die Antwoord and a delegitimised South African Whiteness: A potential counter-narrative? Critical Arts 26:745-61.

Scott, James. 2012. Infrapolitics and mobilizations: A response.' Revue Française d'Études Américaines 131:112-17.

Smitherman, Geneva. 2006. Word from the mother: Language and African Americans. London: Routledge.

Sonnekus, Theo. 2017. Hip Afrikaners and Neo-Tribalism in Post-Apartheid South Africa. Critical Arts 31(4): 18-36.

Steyn, Melissa. 2001. 'Whiteness just isn't what it used to be': White identity in a changing South Africa. Albany: SUNY Press.

. 2004. Rehabilitating a whiteness disgraced: Afrikaner 'white talk' in post-apartheid South Africa. Communication Quarterly 52:143-69.

—. 2005. 'White talk': White South Africans and the management of diasporic whiteness. In Alfred Lopez (ed.), Postcolonial whiteness: A critical reader on race and empire, 119-35. Albany: SUNY Press.

. 2014. De La Rey, De La Rey, De La Rey: Invoking the Afrikaner ancestors. Thamyris/Intersecting 27:133-56.

Steyn, Melissa, \& Don Foster. 2008. Repertoires for Talking White: Resistant whiteness in postapartheid South Africa. Ethnic and Racial Studies 31:25-51.

de Villiers, Marq. 1987. White tribe dreaming: Apartheid's bitter roots as witnessed by eight generations of an Afrikaner family. London: Penguin. 
Visser, Wessel. 2004. Coming to terms with the past and present: Afrikaner experience of and reaction to the 'new' South Africa. Lecture presented at the Centre of African Studies, University of Copenhagen.

Wells, John. 1982. Accents of English. Cambridge: Cambridge University Press.

van der Westhuizen, Christi. 2007. White power and the rise and fall of the National Party. Cape Town: Zebra Press.

Williams, Quentin. 2016. Youth multilingualism in South Africa's hip-hop culture: A metapragmatic analysis. Sociolinguistic Studies 10:109-33.

Williams, Quentin \& Christopher Stroud. 2014. Battling the race: Stylizing language and coproducing whiteness and colouredness in a freestyle rap performance. Journal of Linguistic Anthropology 24:277-93.

Wissing, Daan. 2009. Het jou mô en jou pô 'n strôndhuis by hartenbôs? Feit of fiksie? Southern African Linguistics and Applied Language Studies 24:87-100.

\begin{abstract}
APPENDIX
Lyrics for Baby's on Fire (Justin De Nobrega, Anri Du Toit and Watkin Tudor Jones 2012; ( Sony/ATV Music Publishing LLC)
\end{abstract}

\title{
PROLOGUE
}

Ninja $\quad$ Mmm, this looks lekker, Ma

Mmm, this looks delicious Mom.

Mom Oh, dis 'n plesier

It's a pleasure

Dad Dankie

Thank you

((mother distributes food to everyone around the table $))$

Ninja Ma, is daar nie iets om te drink nie? 
Mom, is there anything to drink?

Mom Yolandi, kry vir jou boetie iets om te drink.

Yolandi, get your brother something to drink.

Yolandi ((sighs))

Dad Yolandi!

Yolandi ((goes to the refrigerator)) Wat soek jy? Coke?

What do you want? Coke?

Ninja Redbull

((Yolandi brings Ninja a Redbull. He drinks the entire can))

((The family joins hands around the table to say grace))

Yolandi Dankie Here vir die lekker kos wat Ma vir ons gemaak het.

Thank you Lord for the delicious food that Mom prepared for us.

En dankie dat al ons konserte so mooi uitverkoop het in die oorsee.

And thank you that all of our concerts sold out so well overseas.

En dankie, Here, dat ek sulke nice klere daar kon gekoop het.

And thank you Lord for the nice clothes that I bought over there.

En dankie Here vir Satan.

And thank you Lord for Satan.

((cut to picture of Ninja with dog named Satan))

Oh, en dankie Here dat ek op die voorblad van die nuwe FHM gaan wees.

Oh, and thank you Lord that I'm going to be on the cover of the next FHM magazine.

En seën asseblief die kos wat ons vandag gaan eet. Amen.

And please bless this food that we are about to eat today. Amen.

Yolandi Mom can JP come show me his new motorbike today?

Ninja Wat? Wie?

What? Who?

Yolandi JP

Ninja No. Not the fuck is that poes coming into this house!

No. Not the fuck is that cunt coming into this house!

I don't want that scumbag motherfucker hanging around my little sister! You hear me? 
Yolandi Aaw, Ma!

Aaw, Mom!

Ninja No, no, no, no. I don't want any of these scaly motherfuckers from this hood getting fresh with my little sister!

They just got one thing on their minds! You hear me? One thing!

Yolandi Whatever. Poes.

Whatever. Cunt.

\section{VERSE I}

Yolandi Showtime, motherfucker it's on.

Apocalypse now, I'm dropping this bomb.

You can't fuck with this song,

I'll stick to this spliff, I'm not klapping [lit. 'hitting'] this bong.

I'm a wild child, I don't wanna go to bed.

Oh, shit man sorry but I'm stoned again.

Ooh, now everything's getting so psychedelic.

When I'm doos dronk ['stupid drunk'] then I forget all my fokken ['fucking'] lyrics.

Like um, uh, who gives a fuck? Don't worry 'bout it, just blow a kiss to me.

I like danger, romance, and mystery.

I'm a lucky ducky, get mad shit for free.

I rock more bling than $\mathrm{Mr}$. $\mathrm{T}$.

I make it look easy cuz it is to me.

My daddy says it's lekker fokken spiff ['very fucking cool'] to see, a South African cherrie ['sexy woman'] making history.

\section{CHORUS}

Ninja Baby's on fire. She's got me going fokken ['fucking'] crazy soos 'n mal naaier ['like a crazy fucker'].

Yolandi O jirre God se Jesus [roughly 'Oh Lord, God's Jesus'].

(repeats x2)

Ninja Baby's on fire. (repeats $\mathrm{x} 3$ )

\section{VERSE II}

Yolandi Hi-Tek, drop that four to the floor.

I get real paid, bitch, what you think I do this for?

My bodyguard help me get to the bar.

Neill Blomkamp's [South African film director] making me a movie star.

A lot of bad boys wanna piece of me.

If you're lucky boy I'll let you sneak a peek.

My zeff style's motherfuckin' freaky-deek,

I don't got beef cuz I don't eat no meat.

I'm on some other shit, yo, I know I speak unique.

Fuck your whole shit up when I freak the beat.

I'm a lucky ducky, get mad shit for free. 
I love it when Kimmy talks sweet to me.

C'mon, Kimmy, Kimmy, Kimmy, speak to me.

I take a trip down memory lane, like yo, fuck fifteen seconds of fame.

I'm a young blood comin' up fresh in the game.

Yolandi Visser, motherfucker, you all remember the name.

\section{CHORUS}

\section{VERSE III}

Yolandi No need to get so deep.

Nothin' quite like a motherfuckin' techno beat.

A techno beat, a techno beat.

A techno, a techno, a techno beat.

Just say what's up, don't try to get so deep.

You know me, maar ek ken jou nie ['but I don't know you'].

Ek ken jou nie. ['I don't know you']

Ek ken jou nie.

Ek ken jou, ek ken jou, ek ken jou nie.

\section{CHORUS + CODA}

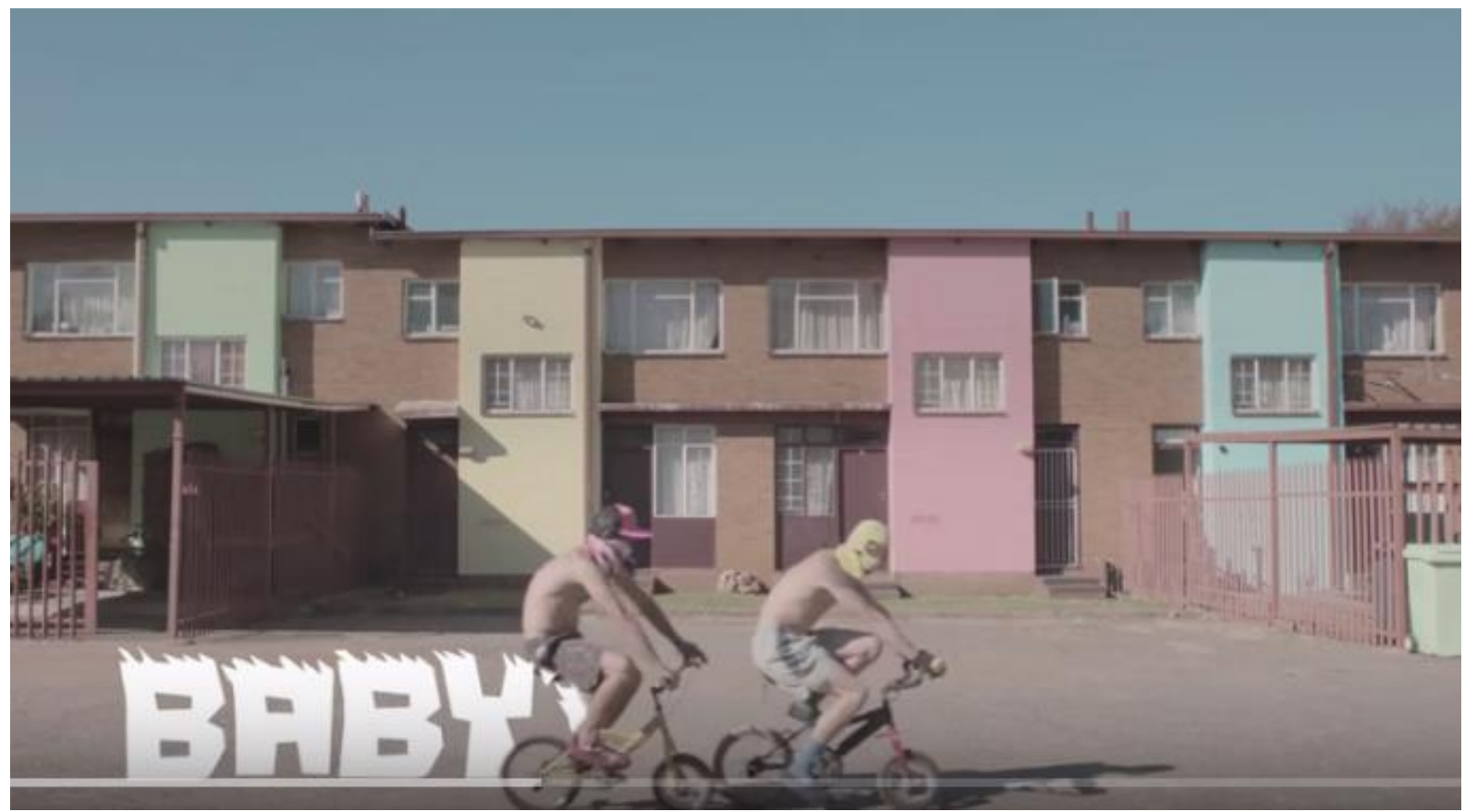


Figure 1: Opening sequence of 'Baby's on Fire' prologue

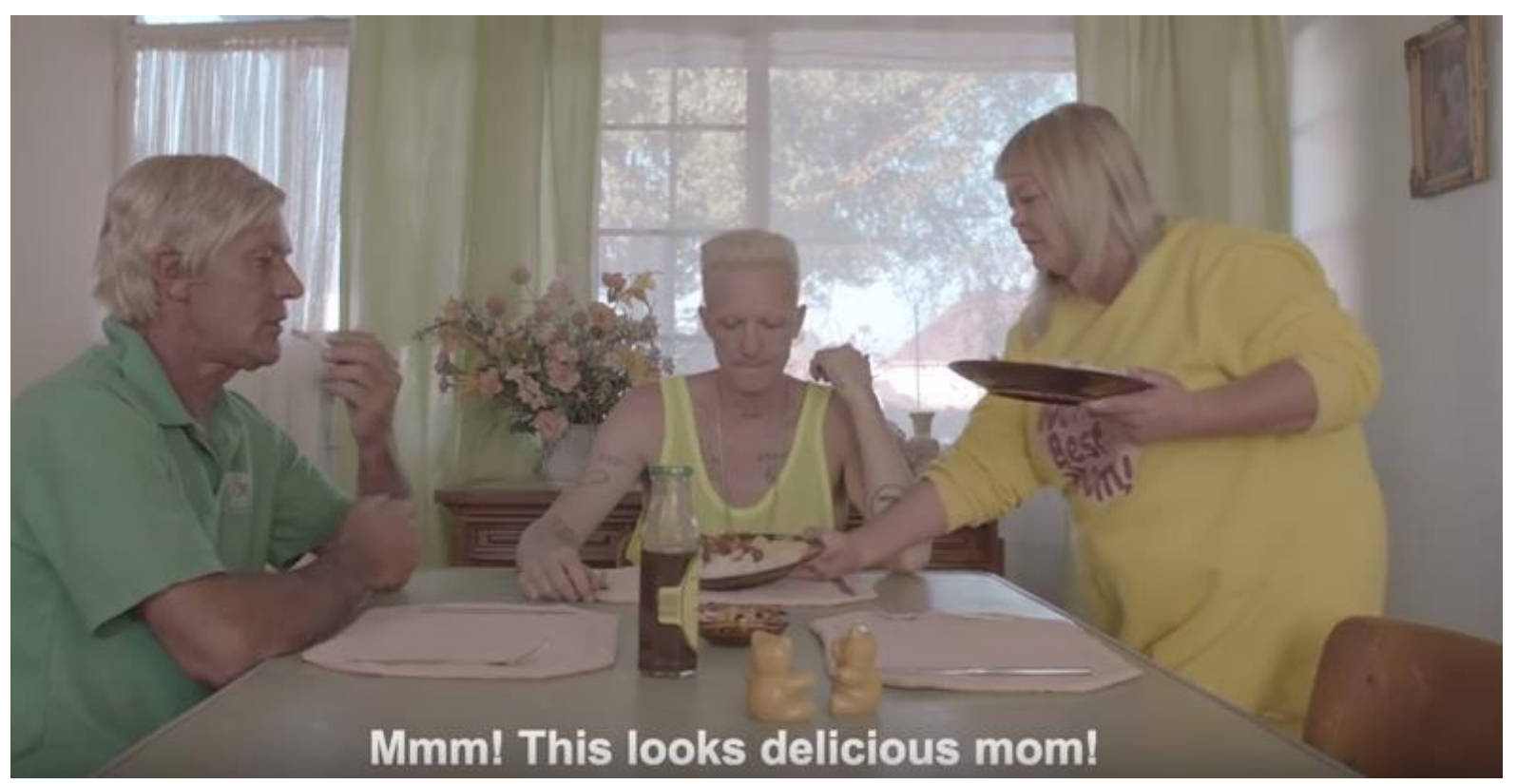

Figure 2: Mother distributing food to Ninja and the father during the prologue
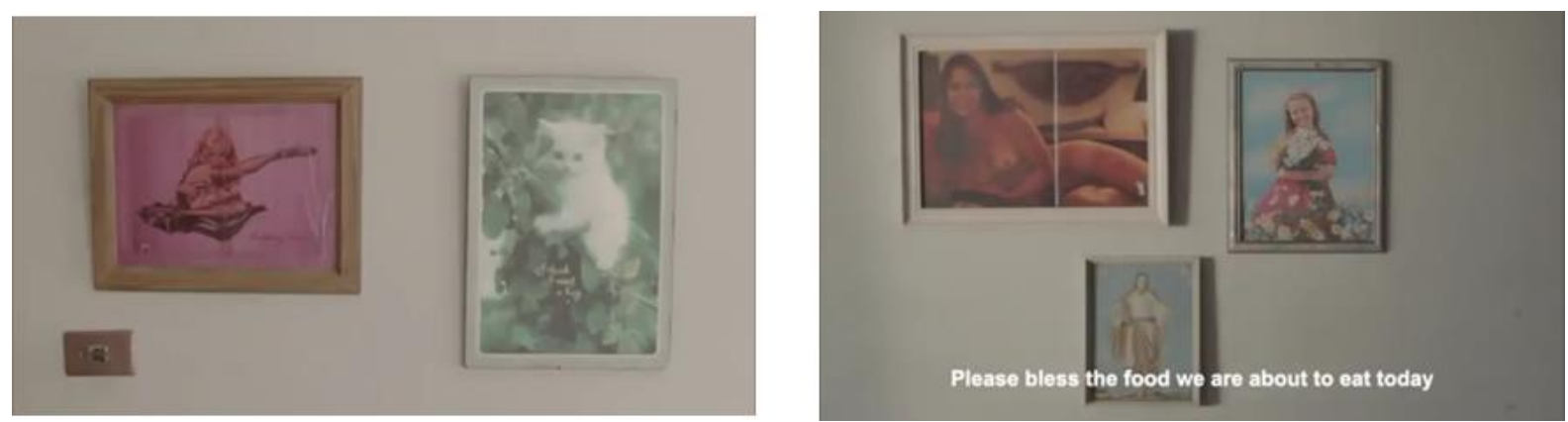

Figure 3. Incongruous juxtapositions of sexual and 'cute' images in the prologue
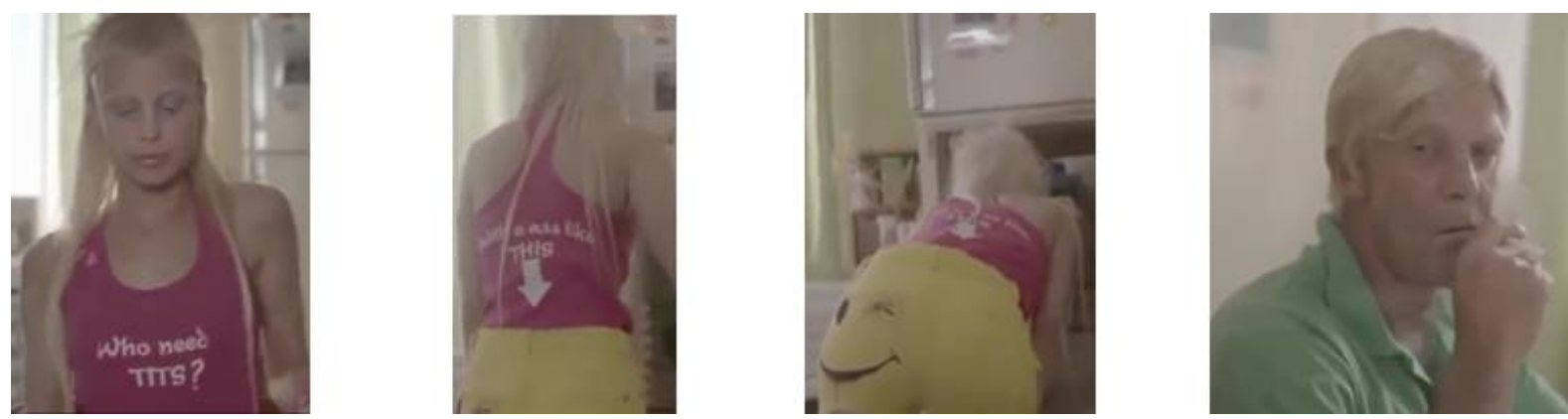
Figure 4. The sexualization of Yolandi in the prologue

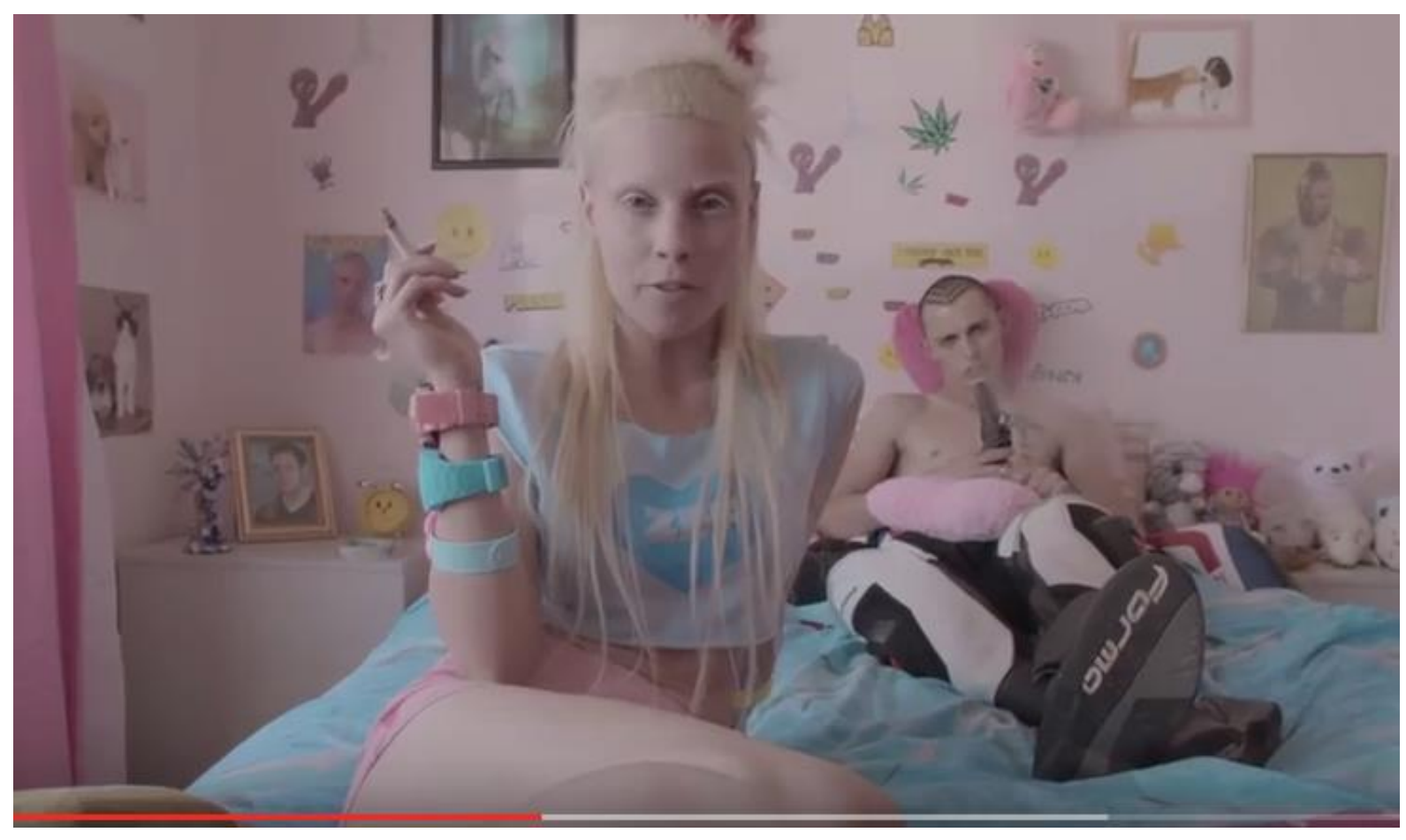

Figure 5. First verse: Yolandi and JP in her bedroom
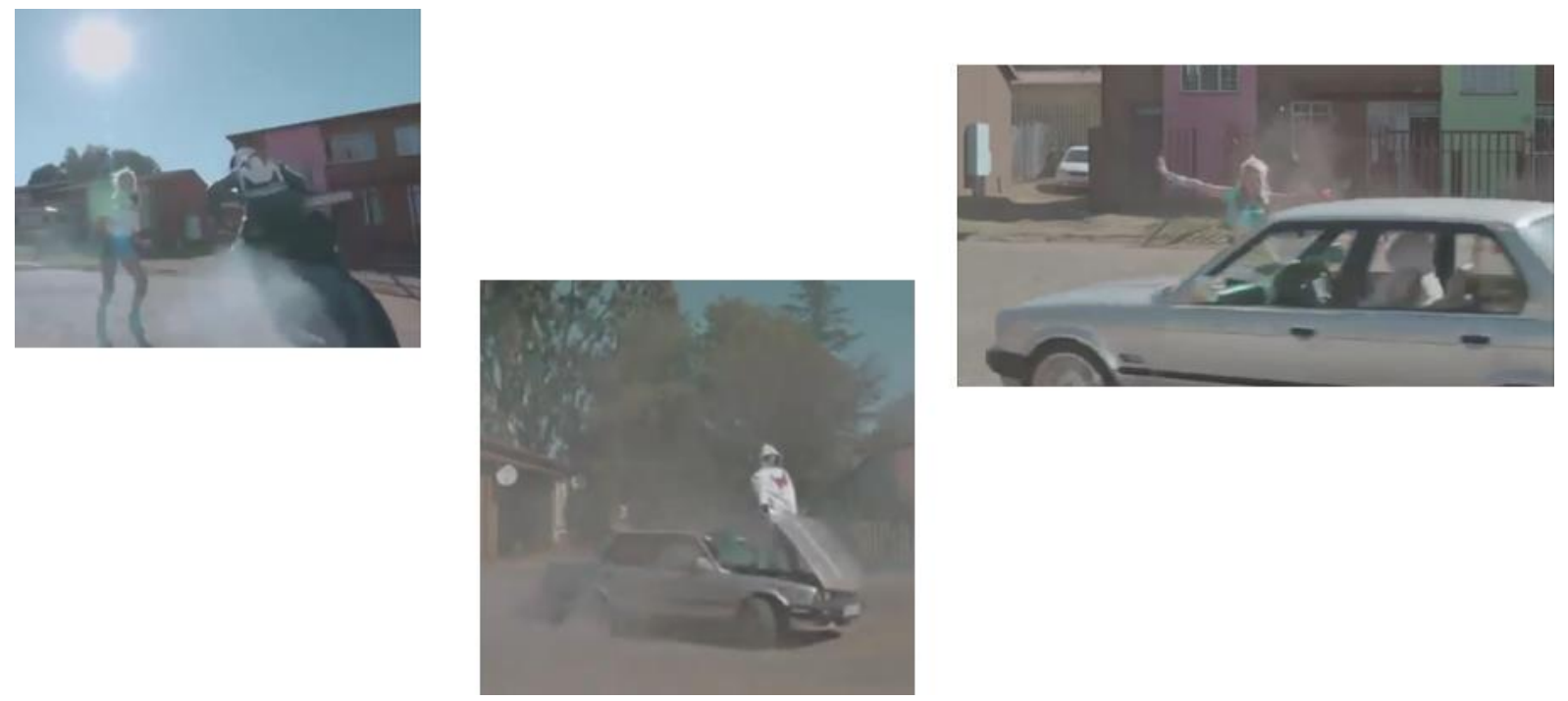

Figure 6. Yolandi and drifting 


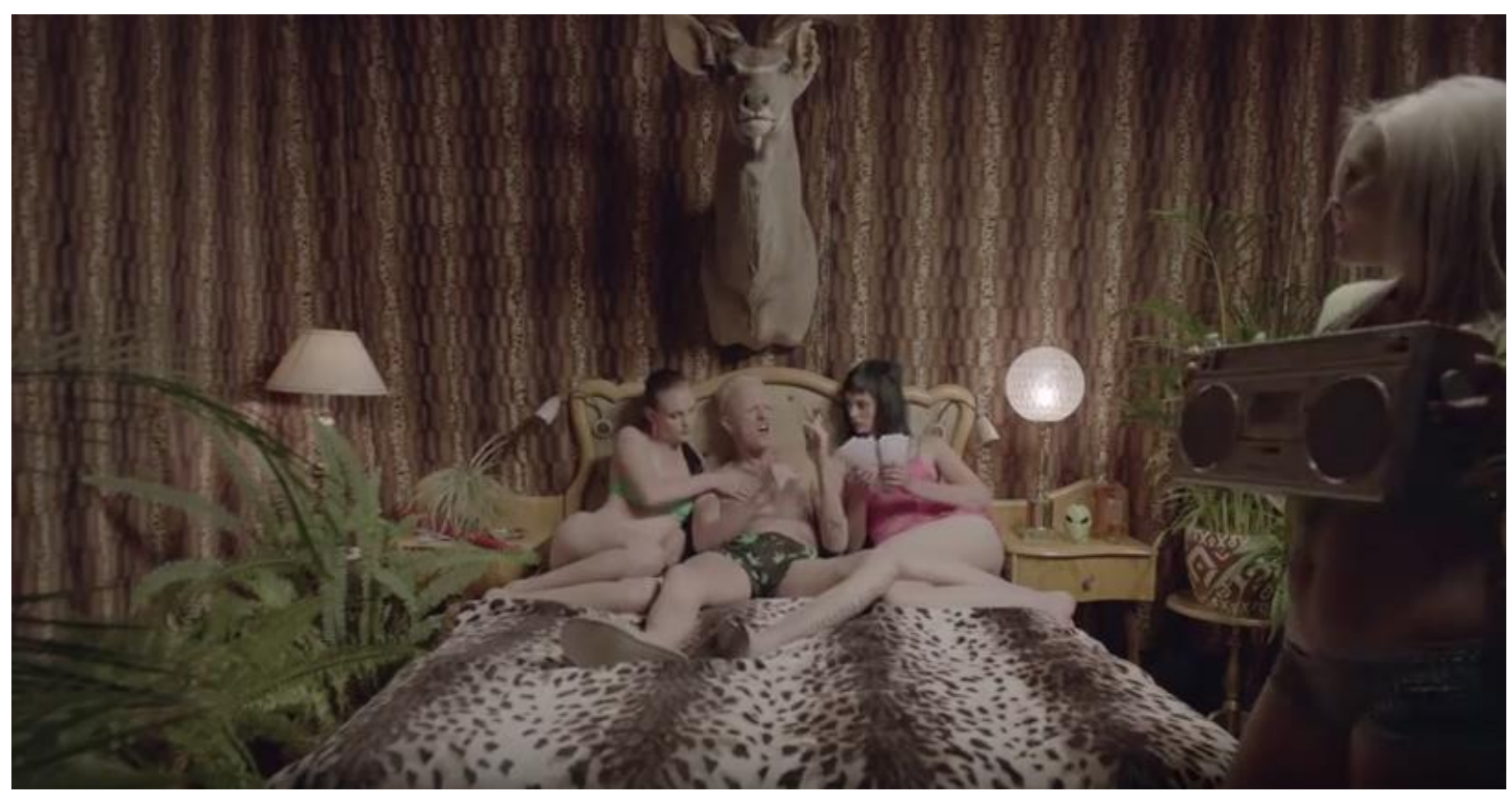

Figure 7. Chorus: Ninja in his bedroom 